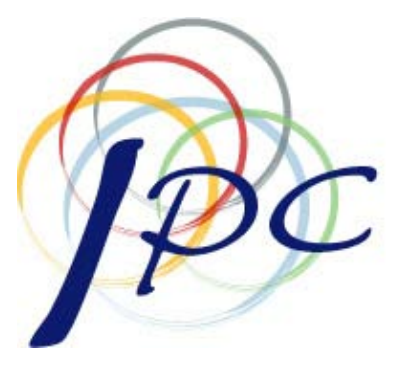

INTERNATIONAL Policy CENTER

Gerald R. Ford School of Public Policy University of Michigan

IPC Working Paper Series Number 96

\title{
Shadow Economy and Entrepreneurial Entry
}

\author{
Saul Estrin \\ Tomasz Mickiewicz
}

June 22, 2010 


\title{
Shadow Economy and Entrepreneurial Entry
}

\author{
Saul Estrin ${ }^{a}$ and Tomasz Mickiewicz ${ }^{b^{\star}}$ \\ ${ }^{a}$ London School of Economics and Political Science \\ ${ }^{\mathrm{b}}$ University College London
}

\begin{abstract}
We analyze theoretically and empirically the impact of the shadow economy on entrepreneurial entry, utilising 1998-2005 individual-level Global Entrepreneurship Monitor data merged with macro level variables. A simple correlation coefficient suggests a positive linear link between the size of the shadow economy and entrepreneurial entry. However, this masks more complex relationships. With appropriate controls and instrumenting for potential endogeneity where required, the impact of the shadow economy on entry is found to be negative, based on a linear specification. Moreover, there is also evidence of nonlinearity: entrepreneurial entry is least likely when the shadow economy is of medium size. We attribute the negative effects of shadow economy on entry to perceived strong competition faced by new entrants when the shadow economy is widespread. At the individual level, an extensive shadow economy has a more negative impact on respondents who are risk averse. In addition, in the economies where property rights are strong, the negative impact of the shadow economy is weaker.
\end{abstract}

Key words: shadow economy, entrepreneurship

JEL Classification codes: O17; D2; L26; P14

\footnotetext{
*We are grateful to Chris Gerry and to Mark Schaffer in particular for an insightful discussion that helped us to develop this paper.
} 


\section{Introduction}

In this paper, we analyse theoretically and empirically the impact of the shadow economy on levels of entrepreneurial activity. Our main concern is whether the likelihood of entrepreneurial entry by an individual is affected by the scale of the shadow economy. The theory yields a number of alternative predictions. The informal sector could be viewed as passive, merely supplying labour to the formal sector at a relatively low fixed wage in a segmented labour market model (i.e. Loayza, 1994; Fields, 2005). In this case, one would expect no particular relationship between entrepreneurial activity and the size of the shadow economy. In contrast, building on the work of de Soto (1990), the informal sector could be regarded as a potential basis for employment creation and growth. Drawing on Latin American experience, Maloney (2004) has argued that the informal sector is in fact best viewed as entrepreneurial; "as a first approximate, we should think of the informal sector as the unregulated developing country analogue of the voluntary entrepreneurial small firm sector found in developed countries" (p.1). This perspective might indicate a positive relationship between country-specific levels of entrepreneurial activity and the size of the shadow economy. However, much of the literature is less sanguine about the operation of shadow economy. De Paula and Scheinkman (2006) focus on tax avoidance as the main determinant of informality, and deduce that informal sector firms will be smaller and will have a higher cost of capital than their formal sector counterparts; hypotheses confirmed on Brazilian data. Such arguments would lead one to expect that levels of entrepreneurial activity will be lower in economies where the shadow economy is larger. Our approach is in the same tradition, but focuses on the impact of segmentation on competition and entry barriers in the two sectors.

The shadow economy itself is returning to the forefront of the policy agenda. For the first time since the establishment of the European Union, one of its member states faces a 
serious fiscal crisis: Greece, with its budget deficit at least at $13 \%$ of GDP in 2009 . It is estimated that about a quarter of the country's value added is created in the shadow economy. Moving this production into the formal economy would generate about 15 billion Euros (20 billion USD) in additional tax revenues. This problem is not new, yet in the past the shadow economy has proved very difficult to reduce. ${ }^{1}$ The economics of institutions indicates why such bad equilbria may persist. In particular, Dixit (2004) presents a formal model of institutional change, in which the mechanics rely on network effects and economies of scale. It may be costly for individual actors, to move out of the informal economy, given that others may not follow. Entrepreneurs who move into the formal economy may then be disadvantaged relative to those who remain in the informal sector. This is an insight upon which we base some of the arguments in this paper.

We suggest that a shift from the informal to the formal economy is hampered by a collective action problem because the effectiveness of the formal economy (and its attractiveness to individual players) is conditional on its widespread acceptance and on compliance. Moreover, the pattern of exchange in the shadow economy relies on informal institutions based on local structures of trust. These imply that the participants develop related network capital, which, once accumulated, represents a sunk cost making people less willing to switch to a system based on formal rules. Thus, even if the origins of the shadow economy may be linked to inefficient government and regulations, once established, the shadow economy can become embedded. It becomes transformed from the level of day-to-day strategies of economic actors responding to taxes, regulation and governance structures to the level of norms and business culture characterised by long term stability (Williamson, 2000). This implies that we need to consider the shadow economy, not just as an economic outcome that varies with high frequency in response to

\footnotetext{
1 "Wall Street Journal Europe", 10"h of February 2010.
} 
current economic incentives, but as a stable element of economic environment representing norms and values, which are difficult to change.

Our paper focuses on the ways in which the existence of a shadow economy might affect the decision of an individual in a particular national context to become an entrepreneur. There is a considerable literature on the determinants of the informal sector, such as regulation, taxation and corruption (Friedman et al, 2000), as well as about its negative effects on tax revenues and the provision of public services (Rauch, 1991; Loayza, 1994; Levy, 2007). However, there has been little explicit empirical treatment of the interrelationship between the informal sector and the processes underlying economic growth such as entrepreneurship. We follow numerous authors from Schumpeter (1934) in regarding entrepreneurship as an economic activity central to the longer term process of development (e.g. Liebenstein, 1968; Baumol, 1990; Acs, 2006; Samuelson, 2009; Wennekers and Thurik, 1999).

Our empirical work is based on the Global Entrepreneurial Monitor (GEM) project, 1998 2005. This is the best choice for our research questions because uniquely it includes data on both formal and informal sector entrepreneurship (see Acs et al, 2008). Our interest is not in the distribution of entrepreneurship between formal and informal activity however, but in the pattern of entrepreneurial activity conditioned by the size of the shadow economy. The latter is measured using the new dataset generated by Schneider and Buehn (2009). We also control for institutional context at the country level using data from the World Bank, Polity IV and Wall Street Journal-Heritage databases.

In our empirical work, we explore the interplay between the size of shadow economy, the 
size of the government, the protection of property rights and entrepreneurial entry, utilising 1998-2005 individual-level Global Entrepreneurship Monitor data merged with macro level variables. The simple correlation coefficient suggests a positive relationship between the size of the shadow economy and entrepreneurial entry. However, this masks more complex causal structures. With appropriate controls and instrumenting for potential endogeneity, the impact of the shadow economy on entry is found to be negative. There are also strong indications of non-linearity: entrepreneurial entry is least likely when the shadow economy is of medium size. We attribute the negative effects of the shadow economy on entry to the perception of new entrants that competition will be stronger where the shadow economy is more widespread. At an individual level, we find that an extensive shadow economy has even greater negative impact on respondents who are risk averse. In addition, in economies where property rights are stronger, the negative impact of the shadow economy on entrepreneurship is relatively weaker.

The following section summarises our hypothesis concerning entrepreneurship, the shadow economy and the institutional environment. The data we employ in our empirical work is presented in the third section, and our estimation methods and econometric issues are presented in the fourth. We present results in the fifth section and draw conclusions in the sixth.

\section{The Shadow Economy, Institutions and Entrepreneurship}

\subsection{The impact of the shadow economy on entrepreneurship}

A potential entrepreneur's decision to enter is likely to be affected by the size of the 
shadow economy. Ceteris paribus, the segmentation of the market into a formal and informal sector implies that a potential entrepreneur may face more competition when initiating her business in the formal sector. This can arise from at least two sources. First, there will be relatively fewer firms in the formal sector, potentially enhancing the market power of incumbents. Second, an entrant also faces competition from the informal sector, which can produce goods or services at lower cost because it does not need to meet government regulations with respect to wages and working conditions and does not pay taxes (De Paula and Scheinkman, 2006).

However, while formal entry may come with its own specific costs, informal entry may also be difficult. In countries where institutions are weak and the informal sector is widespread, we observe a phenomenon of 'insider entrepreneurship' (Aidis et al., 2008): network capital, which is critical for informal business activities, may yield significant advantages for incumbents vis-a-vis (unrelated) newcomers. Since the seminal contribution by De Soto (1989; 2000), we understand the logic of collective action in the shadow economy. It may be characterised by an impressive set of norms representing a self-organisation effort that substitutes for formal rules. At the same time however these informal institutions come with high transactions costs which are likely to bear more on entrants than incumbents. An even darker side of shadow economy may be that it could be associated with criminal structures: while entering the informal sector the entrepreneurs may avoid taxes and regulatory cost but in exchange they may become exposed to organised rackets. Taking those two potential effects related to formal and informal sector correspondingly, we conclude that overall (formal plus informal) entry rates may not be as high in economies with larger informal sectors. 
Additional effects can also be identified. First, the nature of informal sector may change with its size. With an extensive size, the shadow economy may become more ingrained into the economic system and the quality of its institutional arrangements may improve. Consistent with this, a transition from a middle-sized to a large shadow economy may represent a move from the dominance of particular interests to the emergence of encompassing interests. To understand this effect, we may follow Olson's (2000) logic of collective action: it is precisely the extensiveness of the informal sector and the extent of encompassing common interest in solving the collective action problem that may lead to development of a more efficient system of norms. ${ }^{2}$ Using Olsonian terminology, it is likely that with a more widespread and embedded shadow economy, 'warlords' running fragmented rackets become replaced by more functional organisations, as the interests supporting the development of the latter are now more broad. Thus, where the informal sector comes to dominate a significant spectrum of economic activity, it is likely that more sophisticated and functional forms of informal organisation are adopted. This is the case of Peru that De Soto (1989) analyses in his seminal work. He documents the complex informal systems of organisation of exchange in the shadow economy based on consistent expectations formed via repeated behaviour, yet without any foundations in the formal sanction of the law (De Soto 1989; 2000). This possible transformation of the nature of the shadow economy as a function of its size leads us to hypothesise that the impact of the shadow economy on the likelihood of entrepreneurial entry may be non-linear and indeed U-shaped.

\footnotetext{
${ }^{2}$ We apply terminology based on Crawford and Ostrom (1995): norms come without explicit formal sanctions and are supported by informal, social and cultural mechanism. In contrast, rules come with explicitly defined formal sanctions.
} 
Second, the impact of the shadow economy is likely to be less negative in contexts where the opportunity cost of formal entry is high. A government which is very extensive may also be dysfunctional. In this case, as noted by Maloney (2003), the shadow economy may offer an alternative option for entry and facilitate some (second-best) productive use of entrepreneurial talent. Participation in the formal sector may come with such a high opportunity cost that opening up opportunities in the informal sector may actually increase entry, despite the high transaction costs associated with the informal sector.

Third, as argued by Gërxhani (2004), the shadow economy may be different in character in developing and developed countries. In particular, in developed countries informality may be an intermediate stage with new businesses growing and transferring to formal sector. However the key dimension here relates to institutional development. In particular, it is a strong institutional system, represented by effective property rights, that is conducive to entrepreneurship (Aidis et al., 2009). That in turn affects expectations and the propensity to start a new venture. From the individual entrant's point of view, initial informality may indeed represent a useful way to experiment with new ventures that could be transformed into high value added projects later on but this is conditional on strong property rights. Thus, it is a combination of a limited scope of informality coupled with easy opportunities to transfer to formality that is likely to encourage entrepreneurial entry. 
Fourth, entry decisions are conditional on individual attitudes (Harper, 2003) and these may be affected by the size of the informal economy. If potential entrants are concerned with competition from the informal sector, then individuals with higher levels of fear of failure (lower acceptance of risk) may be affected relatively more by the size of the informal sector than those who are not risk-averse.

These interactive effects indicate that it is the configuration of all institutions, not just the size of the informal sector that affects entrepreneurial outcomes. Accordingly, our hypotheses must be framed in the broader context of institutional theory and this is the objective of the next sub-section.

\subsection{A broader context: institutions and entrepreneurship}

Baumol (1990) argues that entrepreneurial activity could take productive, non-productive and even destructive forms, depending on the institutional context. Institutions and the associated incentives and penalties for particular types of economic behaviour determine the balance between these three forms, with higher quality institutions motivating entrepreneurs to choose productive over value-reducing activities. This framework motivates our analysis; the productivity of entrepreneurial entry may vary with the size of the shadow economy. Potential entrepreneurs can be viewed as maximizing their expected return when making a decision to start new ventures (Casson, 1982). The arguments above draw on this framework: potential entrepreneurs make decisions about entry taking into account what we identified as specific costs resulting from the size of the shadow economy. We view the shadow economy not only as a current equilibrium response to varying economic conditions but also as being associated with persistent 
informal institutions. It is this durable component of the shadow economy that justifies considering it as a separate factor affecting entrepreneurial outcomes. Nevertheless, there is a serious risk of misspecification, and while our focus remains on the shadow economy we should carefully identify and control for other important institutional dimensions.

Generally, where formal institutions are functioning effectively, risks are reduced, becoming primarily associated with the nature of the ventures themselves and the characteristics of the individuals' involved (Schumpeter, 1934; Kirzner, 1973). In contrast, weak institutions may increase net returns to non-productive or even criminal activity, reducing incentives to enter (productive) entrepreneurship.

Two specific aspects of the inter-relationship between entrepreneurial activity and institutions have been found to be among the most important in the literature (Johnson et al., 2002; Dermirguc-Kunt et al., 2006; Klapper et al., 2006). The first is the system of property rights. Weaknesses in property rights increase transaction costs, the possibilities to use resources indirectly via contracts and the riskiness of entrepreneurial activity. Recent theories of entrepreneurship emphasise that "the institution of private property ... has an important psychological dimension that enhances our feelings of ... internal control and personal agency, and it thereby promotes entrepreneurial alertness" (Harper 2003, p. 74). De Soto (2000) argues that the lack of a well-defined and efficient system of registering, protecting and trading of property rights may be the key obstacle that prevents the entrepreneurs from utilising and combining the potentially productive assets and turning them into real capital (see also Rodrik, 2000). Acemoglu and Johnson (2005) emphasise the critical role for the functioning of a market economy of effective constraints on the executive branch of the government, and this defines both elements of protection and stability of property rights. In their approach, property rights are akin to the related, 
but slightly wider concept of the rule of law, as the latter corresponds to a stable institutional framework restraining the erratic use of power by politicians and public administrators.

The relationship between property rights and entrepreneurship has been considered in previous empirical work, but the results have been ambiguous. The property rights indicator was not found to be significant by Klapper et al. (2006), Desai et al. (2003) or Demirguc-Kunt et al. (2006). However, Johnson et al. (2002) suggest that the insecurity of property rights may be a key factor deterring investment in small manufacturing firms.

The second cluster of factors concerns the welfare and tax system, which influence both the opportunity cost and the net financial return to entrepreneurial activity. Here, we consider the impact of the extent of the government sector on entrepreneurship. In general, a larger government sector will militate against entrepreneurial activity, both via state revenues and expenditures. Taxes and welfare provision may affect entrepreneurial entry via their direct impact on expected returns to entrepreneurial activity and its opportunity cost. High and increasing marginal level of taxes may weaken incentives for opportunity-driven entrepreneurship by reducing potential gains, while high levels of welfare support provide alternative sources of income and therefore by increasing the alternative wage may reduce the net expected return to entrepreneurship. Taken together, this indicates that a larger state sector will crowd out entrepreneurial activity.

In our empirical design, we take these two institutional dimensions into account, as well as considering the interactive effects discussed above. 


\section{Data}

\subsection{Macro Level Data}

The size of the shadow economy is not directly observable. Estimates are taken from a new dataset generated by Schneider and Buehn (2009). Their approach builds on the previous literature (Schneider and Enste, 2000) and it combines two alternative methods of estimation. The first, a more traditional one, is based on currency demand, where the unexplained residual demand for money is taken as a proxy for the size of the informal sector. The second approach is a latent estimation model that uses a structure of equations, in which an unobserved variable, in this case the size of the shadow economy, is related to a number of observable indicators, which in addition to the excess demand for cash include the unexplained element in participation rates: observed participation rates in the formal economy tend to be low where shadow economy is large. A second set of equations link the shadow economy to a number of factors that are expected to affect its size. These include business regulation, unemployment and the size of government transfers.

As noted above, we also focus on two institutional characteristics: property rights and the size of the government. Following Acemoglu and Johnson (2005), we use effective constraints imposed on the arbitrary power of the executive branch of the government as the main (and most exogenous) indicator of protection of property rights, taking this measure directly from the Polity IV database. As a measure of the size of the government, we take the share of government expenses in GDP, which include not just final government consumption (government expenditures) but also all transfers (data comes 
from World Bank, World Development Indicators). ${ }^{3}$

The shadow economy is related to the level of economic development - high income countries tend to have smaller informal sectors. Moreover, several studies have documented the existence of a relationship between entrepreneurial activity and economic development (Wennekers et al. 2005; Carree et al. 2002; Acs et al. 1994). We control for this by including a measure of per capita GDP at purchasing power parity (PPP). The literature has also been concerned with the link between the overall (cyclical) economic performance in a country and the incentives to entrepreneurial entry. Two conflicting effects may occur, and it is difficult to decide a priori which has the stronger impact. On the one hand, entrepreneurship may be 'recession-push', as the opportunity cost of entrepreneurial entry is lower when existing firms are not expanding, which reduces new job openings. On the other hand, there may be also 'prosperity-pull' effect; that is, a growing economy leads to larger expected gains from entrepreneurial activity (Parker, 2004). The rate of economic growth measured by GDP growth has been shown by Van Stel et al. (2007) to have a positive effect on the rate of opportunity entrepreneurship. In our models we include GDP growth as a control variable.

\subsection{Individual Level Data}

The data on entrepreneurship and individual-level variables are taken from the GEM

\footnotetext{
${ }^{3}$ In our empirical work it is difficult to distinguish between the size of government expenses and the size of government revenue due to the very high level of correlation between the two. There is no easy way to disentangle the two sides of the government and one should be aware of this ambiguity when interpreting the results.
} 
project, 1998-2005. GEM data are generated through surveys creating stratified samples of at least 2,000 individuals per country. The sample is drawn from the whole working age population in each participating country and therefore captures both entrepreneurs and non-entrepreneurs. While data on business ownership and individual business financing is included, entrepreneurial activity is defined here as new, nascent start-up activity. Nascent entrepreneurs are defined as those individuals between the ages of $18-64$ years who have taken some real action toward creating a new business in the past year, and expect to own a share of those businesses they are starting, which must not have paid any wages or salaries for more than three months yet (Minniti et al., 2005). In contrast, established entrepreneurs are defined as individuals who own or manage a company and have paid wages or salaries for more than 42 months (ibid.). We utilise all available GEM data from the 1998-2005 surveys. The individual countries that are included in our sample are those reported in Figure 1 below.

The most common controls for personal characteristics influencing entrepreneurship in the literature are for age and human capital. The relationship between entrepreneurship and age is typically found to be inverse- $U$-shaped, with the maximum found at a relatively young age (Levesque and Minniti, 2006) and we use a quadratic control in our equations. Robinson and Sexton (1994) and Cooper and Dunkelberg (1987) find that the decision to become self-employed is influenced by education while the results of Delmar and Davidsson (2000) and Davidsson and Honig (2003) show an education effect for nascent entrepreneurs. More recent evidence compiled by Parker (2004) suggests that on average, entrepreneurs tend to be more educated than non-entrepreneurs.

Wennekers et al. (2005) found a significant and positive relationship between the 
incumbent business ownership and entrepreneurial start-ups. Role models may for example help by providing information, which alleviates both uncertainty and the cost of starting the business (Minniti, 2005). We therefore also control for whether the potential nascent entrepreneur knows other entrepreneurs. In addition, the likelihood of a start-up may be influenced by whether the potential entrepreneur is employed while deciding to start her business.

In addition, following Harper (2003) we take into account that the entry decisions are affected by attitudes; by self-confidence and the attitude towards risk in particular. Based on GEM questionnaire, these two dimensions are captured correspondingly by confidence that own skills are sufficient to start a business and by lack of fear of failure; as a proxy for the latter, the GEM survey asks the respondents if fear of failure would be strong enough factor preventing them from starting a new business.

Definitions and descriptive statistics for all variables are presented in Table 1 below. These are not statistics based on the whole sample but on the observations actually used in estimations, so the joint effect of being missing in data is taken into account.

\{Table 1 about here\} 


\section{Estimation Issues and Specification}

\subsection{Correlations}

Simple correlation coefficients between the key macro variables are reported in Table 2 . We observe a weak positive correlation between the size of the shadow economy and entrepreneurial entry (combined formal and informal entry). ${ }^{4}$

\{Table 2 about here\}

We argued above that the negative impact of shadow economy size on the likelihood of start-up may be linked to greater levels of competition faced by potential entrepreneurs at time of entry. A proper measure of this effect would have to relate to all respondents; unfortunately we do not have one at our disposal. The one we have, based on the GEM questionnaire, is a question that was asked only to those respondents that are actually involved in start-up. That implies a selectivity bias and means that we cannot use this variable in the econometric work which follows. However, it is still revealing to note the correlations between perceptions of competition by new entrepreneurs and the extent of the shadow economy. The GEM survey asks nascent entrepreneurs about their expectations on the level of competition, distinguishing between many competitors (coded as 1), some competitors (coded as 2) and no competitors (coded as 3). Table 3 below documents that there is a significant correlation between the competition measure and the size of the shadow economy: the more extensive is the shadow economy, the greater the

\footnotetext{
${ }^{4}$ There is a potential group of outliers: the post-Soviet economies are characterised by both large shadow economy sectors and low rates of entrepreneurial entry. The low level of entrepreneurship in transition economies is consistent with Estrin and Mickiewicz (2010). However, in our econometric work below, we verified that, when an additional dummy representing the transition economies is added to the estimated equations, it is never significant.
} 
perceptions of stronger competition. Moreover, when we restrict the sample of nascent entrepreneurs only to those involved in high growth projects (those expecting to create 10 jobs or more), this correlation becomes even stronger: the coefficient doubles in value from 0.07 to 0.15 . This has important implications for efficiency because these projects are particularly significant from the economic point of view.

\{Table 3 about here\}

\subsection{Endogeneity of the shadow economy}

Broad correlations provide a first approximation, but may be misleading due both to their bivariate nature (omitted variables) and the difficulty in interpreting the results because of potential endogeneity issues. We start with the discussion of the latter. An advantage of our empirical design is that we can exclude one important type of endogeneity, namely simultaneity bias. As discussed, our dependent variable is a indicator that takes a value of one if a respondent is involved in a start-up activity. This is regressed on individual characteristics and country level variables. The latter, including the size of the shadow economy, are of particular interest to us. At the same time, it is difficult to see any foundation for the simultaneity bias: an individual entry decision cannot have any significant feedback effect on aggregate country level outcomes. However, this argument does not exclude all types of endogeneity; in particular if there are aggregate reverse effects from entrepreneurship to the shadow economy, those may still induce some weak residual correlation between the dependent variable and the error term that applies to individual level observations.

For that reason, for each equation we run, we investigate if there is any indication of 
endogeneity and use instruments for the shadow economy where necessary. The choice of such instruments is not a trivial task. Our strategy is to identify possible instruments and check for robustness by applying alternative models. We consider two possible instruments:

(1) the durability of democracy, as proxied by a number of years a country spent under a democratic regime uninterrupted (from Polity IV), and

(2) an indicator of the level of business regulations (from Wall Street Journal - Heritage Foundation dataset).

Our choice can be justified both on theoretical and on empirical grounds. First, we have argued that the shadow economy is not just a short-run equilibrium outcome, but an embedded informal institution. Therefore, we look for variables that are likely to correlate with longer-term informal institutions but not with the short term characteristics of entrepreneurial entry. From this point of view, the durability of democracy is an appropriate measure. It captures a long-term institutional tradition, and it is in the long term perspective that formal and informal institutions converge: the long term formal institutional setup affects culture and norms, and vice versa. This is consistent with the concept of 'democratic capital' as discussed by Persson and Tabellini (2006).

Our second, instrument is an indicator of the extent to which business is regulated. We argue that in the context of a shadow economy, while regulations are likely to have an impact on the choice between formal and informal entry, they are less likely to affect the overall entry decision, and it is the latter that corresponds to our dependent variable. Thus, the extent and cost of business regulations will be associated with the size of the shadow economy as a result of an increased opportunity cost of doing business in the formal 
sector, but not necessary with the entry decision per se. This is exactly what should be expected from a good instrument. These intuitions are confirmed by the fact that the correlations between both instruments and the dependent variable (entrepreneurial entry) are very weak, as reported in Table 4 below.

\{Table 4 about here $\}$

Table 4 indicates that both instruments are strongly correlated with the shadow economy. However, a far better method to assess if the chosen instruments are not weak is to consider the correlation coefficients between the residuals from the following two equations: one, where an endogenous variable (shadow economy) is regressed on all other explanatory variables, and another where the chosen instrument is regressed on the same set of variables. For business freedom, the correlation coefficient between those residuals is -0.33 , and for democratic durability it is -0.08 . This indicates that business freedom is a strong instrument for the shadow economy. In turn, democratic durability is a little weaker. Hence, we use business regulation as our chosen instrument, but also report specifications which use democratic durability and both instruments, to demonstrate that our results are not driven by the choice of any particular instrument.

\subsection{Further estimation issues}

Entrepreneurial entry is affected by other macro level variables and it is not easy to isolate the impact of the size of shadow economy. On the one hand, ignoring relevant macro variables leads to specification error due to omission, but on the other including too many indicators leads to multicollinearity and a risk that the direction and magnitude of effects is 
forced by over-specification. As noted above, we focus on property rights and the size of the government as the two key institutional dimensions for entrepreneurship. For property rights, we follow Acemoglu and Johnson (2005) and use constraints on the executive branch of the government as the basic (and relatively exogenous) predictor of lack of arbitrariness in government actions. For the size of the government, we take the ratio of government expenses to GDP. In addition to the theoretical justification, both of our chosen indicators are only weakly correlated with the size of the shadow economy, alleviating multicollinearity.

In our estimations, we rely on maximum likelihood probit estimator and apply GEM population weights. We also cluster standard errors on country-years and include time fixed effects. We take this estimation strategy as being superior to the use of country fixed effects for several reasons: (i) the GEM panel is highly unbalanced with many countries observed in just one year; (ii) variation over time (which is the basis for country-fixed effects models) in institutional indicators is problematic because measurement in institutional indicators is imperfectly dated and most of the short-term time variation represents measurement error; (iii) given the sample size, using country fixed effects instead of clustering on country-years would produce low standard errors and boost significance levels artificially. Thus while coefficients would be more significant, it is problematic to interpret what they actually measure; in short panels meaningful institutional variation is all cross-sectional.

However, it is important to control for correlation between observations within each of the destination countries by clustering standard errors on the latter. Clustering standard errors enables us to relax the standard but unrealistic assumption of independence of all 
observations. As a result, reported standard errors are measured more accurately, while values of coefficients are not affected. We assume that observations are distributed over a number of clusters (countries) $C_{1}, C_{2}, \ldots, C_{N}$ and that these clusters are independent. Accordingly, a standard robust estimator of variance given by $\hat{V}=\widehat{\boldsymbol{V}}\left(\sum_{k=1}^{N} u_{k}^{\prime} u_{k}\right) \hat{\boldsymbol{V}}$, where the estimator of variance is given by $\widehat{\widehat{V}}$ and vectors $u$ represents contributions of individual observations used for weighting is now replaced by $\widehat{V}=\widehat{\boldsymbol{V}}\left(\sum_{k=1}^{N} \boldsymbol{u}_{k}^{(C) s} \boldsymbol{u}_{k}^{(C)}\right) \widehat{\boldsymbol{V}}$, where $\boldsymbol{u}_{k}^{(C)}$ represents a contribution of cluster $k$.

Our specification strategy is as follows. We estimate equations for an individual choice to be engaged in a start-up and include all the individual and macro level variables discussed above. We start with a linear specification for the shadow economy but go on to consider non-linearities using both a logarithmic transformation of the shadow economy and a cubic one. Finally, we introduce interactive effects between the shadow economy and: the size of the government, the protection of property rights, the fear of failure as captured on individual level. These specifications correspond to our priors as discussed in section 2.1 above. For each of our models we report results based on the three alternative instrumentation strategies. Where endogeneity tests cannot reject the null, we also report results based on models with no instrumenting.

\section{Econometric Results}

Our results are reported in Tables 5-7 below. Specifications (1)-(3) relate to models where the share of shadow economy in GDP is entered in linear form, but based on alternative instruments. Specifications (4)-(6) report the models with the share of shadow economy transformed into natural logarithm. We find that the shadow economy has a negative 
impact on entry, and is significant in all six models.

All these results come from specifications where we also find other significant institutional effects. Protection of property rights has a positive impact on entrepreneurial entry, being significant in most specifications, though it is insignificant where durability of democracy is used as an only instrument. One possible reason for this sensitivity is that strong constraints on executive branch of the government are positively correlated with democratic durability so some degree of multicollinearity is being introduced. In contrast, the size of government as proxied by the ratio of expenses to GDP always retains a highly significant negative impact and higher levels of GDP per capita is also always associated with less entrepreneurial entry, though the relationship is nonlinear, as captured by logarithmic specification. In turn, the impact of the annual variation in GDP growth, which is our proxy for economic opportunities, is highly insignificant and changes sign between equations. We also run the models without GDP growth rates but other results were not affected (not reported, but available on request). The individual level effects are all consistent with existing research as discussed above.

After those benchmark specifications we next turn to a cubic specification of the shadow economy. To understand why this has an empirical appeal, consider Figure 1 below. To show the pattern more clearly, we use country level averages and given that we control for GDP per capita (PPP) in our models, as a measure of shadow economy we use residuals from a regression of the size of the shadow economy on GDP per capita. The two curves on the outside of the cubic approximation on Figure 1 show the $5 \%$ confidence intervals. On the left hand side of the graph we see countries with a relatively smaller shadow economy relative to that predicted by their level of development. They are also 
characterised by relatively high start-up rates. We find for example Jordan, Chile and New Zealand in that group. Next we have countries with a shadow economy a size consistent with their level of development, in the medium range. Entrepreneurial entry tends to be weak in this group, which includes Sweden, France, Slovenia, Hungary and Japan amongst other. Finally, we have countries with a larger shadow economy than expected at a given level of development, but where entry rates are also high. We find Brazil, Uganda and Peru in this group.

\{Figure 1 about here\}

A cubic in the shadow economy is entered in probit models (7)-(11) reported in Table 6 below. Specifications (7)-(9) are where the shadow economy is instrumented using the three alternative options discussed above. The signs of the linear and cubic terms come as consistently significant and with the expected sign: first negative and next positive, as with Figure 1. It is also interesting to note that endogeneity is no longer a problem, based on insignificant results of the Wald test (related to athro in Table 6). This suggests that the endogeneity issues we encountered previously may be associated with failing to account for more complex non-linearities linking the size of the shadow economy with entry. Based on these results, we run model (10) where no instruments for the shadow economy are used. Again, both terms of the shadow economy have the expected signs and we confirm that stronger property rights are associated with a higher likelihood of entry and a larger size of the government is associated with a lower likelihood of entry.

Equation (11) offers an additional test. Given that Peru is a clear outlier (see Figure 1), it could be that the non-linear effect is largely driven by this country. Therefore, we replicate 
the earlier model excluding Peru. While the size and significance of the cubic effect is reduced, our previous findings still hold.

We also ran a specification which includes a dummy for transition economies which have significantly lower levers of entrepreneurship for their level of development (Aidis et al, 2008). Figure 1 shows that the transition economies, Russia, Latvia and Slovenia in particular, tend to be located in the lower right hand corner of the graph: with shadow economies larger than what is predicted by their level of development. We find that, with the transition dummy added, the cubic effect gains in significance: it is now significant at the 0.001 level. However, the transition dummy is itself marginally insignificant, so we neither report nor consider it further (available on request).

We next turn to alternative specifications of nonlinearity, by introducing the three interactive effects discussed in sections 1-3. These are between the size of the shadow economy and (i) the individual's lack of fear of failure (ii) the size of the government, and (iii) the protection of property rights. We first run three models, where we add each of these interactions separately to the equation where the shadow economy enters in linear form.

In all these models, our interactions have expected signs and are significant. The coefficient on the interaction between the lack of fear of failure and the shadow economy has a positive sign. This suggests that the respondents who are less risk averse are also less affected by the size of the shadow economy. The interaction between shadow economy and government size is also significant, implying that a negative impact of a larger government on entry may be alleviated by the presence of shadow economy, as it 
creates some alternative second-best opportunities for entry. Finally, the interactive term between strong property rights and the shadow economy is also positive, which may be seen as consistent with Gërxhani (2004): in countries with higher quality institutions, the shadow economy may play a role of introductory stage where new entrepreneurs test their skills while remaining informal. At the same time, higher quality institutions provide them with attractive opportunities to become formal so as to realise the full potential of their projects later on. Expectations of such a scenario will affect the likelihood of entry. However, while suggestive, all the interactive results discussed here may suffer from misspecification, because the cubic term of the shadow economy has not been introduced, though our evidence suggests this specification is superior to the linear one. Therefore, robust test for these additional interactive effects require that the shadow economy is entered in both linear and cubic terms, as is done in models (12)-(14) and reported in Table 7. Once this more stringent test is performed, only the third interactive effect remains significant (specification (14)). That is, it is where property rights are strong that the shadow economy may play some positive role. Again, we interpret this result in line with Gërxhani (2004): with higher quality institutions, an entrepreneur may enter the market via informal channels, but she has the opportunity to realise the full potential of her venture in the formal sector later on.

All the results reported so far have been concerned with the determinants of the likelihood of entrepreneurial entry, regardless of the characteristics of the new venture. However, as argued by Estrin et al. (2009), it may be more important from the policy point of view to focus on a narrower category of entry: new start-ups with significant growth potential. For that reason, we replicate all our estimations using an alternative dependent variable. We now only consider entry which is associated with aspirations of creating 10 jobs or more, 
which may be labelled high growth aspiration entrepreneurship. While, those are only expectations at time of entry, they have strong predictive power for subsequent outcomes and therefore may be taken as a good indicator of the new venture dynamism. These additional tests reported in Tables 8-10, fully verifying the robustness of our previous results on this narrower category of entry. In particular, we confirm that the shadow economy has a non-linear effect on high growth aspirations entry and that there is a significant positive interactive term between the shadow economy and property rights. The key difference between the two sets of results is that the level of development (as represented by GDP pc PPP) is consistently insignificant. This implies that, while overall entry rates are lower in countries at a higher level of development, this does not apply to higher growth potential projects. Thus, the composition of entrepreneurial entry in rich countries changes as the share of higher value added projects increases.

\section{Conclusions}

This is the first cross-country study that deals with the impact of the size of the shadow economy on likelihood of entrepreneurial entry in general, and on likelihood of entry into high growth aspiration activities. We find that the likelihood of entry decreases with the size of the shadow economy. These results are corroborated by our finding that when the shadow economy is larger, entrepreneurs perceive more competition at time of entry decision which may deter them from starting new businesses. Moreover, this perceived competition effect, conditional on the size of the shadow economy, is stronger for high growth aspiration projects.

However, as illustrated by Figure 1, and confirmed by specifications reported in Tables 6-7 
and 9-10, the negative effect of larger shadow economy may be reversed at a large size. We interpret this as suggesting that where shadow economy is large, it becomes institutionally embedded generating a set of norms for economic transactions, which provide an alternative order for economic organisations. Within our data, this case is best illustrated by Peru, entirely in line with an analysis of the functionality achieved by informal organisations demonstrated by De Soto $(1989,2000)$. We suggest that this transformation of the shadow economy from disruptive into a more efficient self-organisation is consistent with Olsonian stress of importance of encompassing interests (Olson, 2000). Thus, the likelihood that an efficient alternative form of economic order emerges may increase as the size of the shadow economy rises. However the path-breaking analysis of De Soto (1989) should not be generalised to all cases: Peru may not be representative of other middle income and developing countries and overall the impact of the shadow economy on entrepreneurial entry is disruptive. In addition, we found that the shadow economy may have a less negative effect on entrepreneurship in economies characterised by strong property rights: in that case, an initial phase of informality may transfer to the formal sector, resulting in realisation of a full potential of a successful project, in line with Gërxhani (2004).

\section{References}

Acemoglu, Darren and Simon Johnson (2005). "Unbundling Institutions", Journal of Political Economy, 113 (5), 945-995.

Acs, Zoltan, David Audretsch and David Evans. 1994. "Why does the self-employment 
rate vary across countries and over time?" Discussion Paper 871. London: CEPR.

Acs, Zoltan, Sameeksha Desai and Leora Klapper (2008). "What Does

>>Entrepreneurship<< Data Really Show? A Comparison of the Global Entrepreneurship Monitor and World Bank Group Datasets", Policy Research Working Paper No 4667.

Washington: World Bank.

Aidis, Ruta, Saul Estrin and Tomasz Mickiewicz (2008), "Institutions and

Entrepreneurship Development in Russia: A Comparative Perspective", Journal of

Business Venturing 23: 656-672.

Aidis, Ruta, Saul Estrin and Tomasz Mickiewicz (2009), "Entrepreneurship in Emerging Markets: Which Institutions Matter?", IZA Discussion Paper No 4123.

Baumol, William. 1990. "Entrepreneurship: productive, unproductive, and destructive". Journal of Political Economy 98 (5): 893-921.

Buehn, Andreas and Friedrich Schneider. 2009. "Corruption and the Shadow Economy: A Structural Equation Model Approach", IZA Discussion Papers 4182.

Carree, Martin, André van Stel, Roy Thurik and Sander Wennekers. 2002. £Economic Development and Business Ownership: An analysis using data of 23 OECD countries in the period 1976 - 1996". Small Business Economics 19 (4): 271 - 290

Casson, Mark. 1982. The Entrepreneur. An Economic Theory. Oxford UK: Martin Robertson.

Cooper, Arnold C. and William Dunkelberg (1987). „Entrepreneurial Research: Old Questions, New Answers and Methodological Issues". American Journal of Small Business 11 (3): 11-23.

Crawford, Sue and Elinor Ostrom (1995) "A Grammar of Institutions", The American Political Science Review, 89 (3), 582-600.

Davidsson, Per and Benson Honig. 2003. "The Role of Social and Human Capital 
among Nascent Entrepreneurs". Journal of Business Venturing 18 (3): 301-331

Delmar, Frédéric and Per Davidsson. 2000. "Where do they come from? Prevalence and characteristics of nascent entrepreneurs". Entrepreneurship and Regional Development 12 (1): 1-23.

Demirguc-Kunt, Asli, Inessa Love and Vojislav Maksimovic. 2006. "Business Environment and the Incorporation Decision". Journal of Banking and Finance 30 (11): 2967-2993.

Desai, Mihir, Paul Gompers and Josh Lerner. 2003. „Institutions, Capital Constraints and Entrepreneurial Firm Dynamics: Evidence from Europe". Harvard Negotiation, Organizations and Markets Research Papers 03-59.

De Soto, H. 1989. The Other Path: The Invisible Revolution in the Third World. New York: Harper Collins.

De Paula, Aureo and Jose A. Scheinkman. 2006. "The Informal Sector”, Levine’s Bibliography, 122247000000001030, UCLA Department of Economics.

De Soto, H. 2000, Mistery of Capital, New York: Basic Books.

Dixit, A. 2004, Lawlessness and Economics, Princeton: Princeton University Press.

Estrin, S., Korosteleva, J. and T. Mickiewicz, 2009, "Better Means More: Property Rights and High-Growth Aspiration Entrepreneurship", IZA Discussion Paper No 4396.

Estrin, S. and T. Mickiewicz (2010) "Entrepreneurship in Transition Economies: The Role of Institutions and Generational Change", in: M. Minniti (ed.) The Dynamics of Entrepreneurial Activity (Oxford: Oxford University Press), forthcoming.

Fields, Gary S. 2005. "A Guide to Multisector Labor Market Models, A World Bank Social Protection Unit Discussion Paper No. 0505

Gërxhani, Klarita (2004). "The Informal Sector in Developed and Less Developed Countries: A Literature Survey", Public Choice, 120 (3/4), 267-300. 
Harper, D. 2003. Foundations of entrepreneurship and economic development. Abingdon: Routledge.

Johnson, Simon, John McMillan and Christopher Woodruff. 2002. "Property Rights and Finance" American Economic Review 95 (5): 1335-1356.

Kirzner, Israel. 1973. Competition and Entrepreneurship. Chicago IL: University of Chicago.

Klapper, Leora, Luc Laeven and Raghuram Rajan. 2006. Entry Regulation as a Barrier to Entrepreneurship. Journal of Financial Economics, 82 (3): 591-629

Levesque, Moren and Maria Minniti. 2006. "The Effect of Aging on Entrepreneurial Behavior". Journal of Business Venturing 21 (2): 177-194.

Liebenstein, H. 1968. "Entrepreneurship and Development". American Review, 58

Maloney, 1999. "Does Informality Imply Segmentation in Urban Labor markets?

Evidence from Sectoral Transitions in Mexico. The World Bank Economic Review, 13, 275 $-302$

Minniti, Maria. 2005. "Entrepreneurship and Network Externalities". Journal of Economic Behavior and Organization 57 (1): 1-27.

Loayza, Norman V. 1994. "Labor regulations and the informal economy" Policy Research Working Paper Series 1335, The World Bank

Minniti, Maria, William Bygrave and Erkko Autio. 2005. Global Entrepreneurship Monitor. 2005 Executive Report. Babson College, MA, US and London Business School, UK. Retrieved April 1, 2010 from http://www.gemconsortium.org

Maloney, William. 2003. "Informal Self-Employment: Poverty Trap or Decent Alternative?" in Gary S. Fields and Guy Pfeffermann, Pathways out of Poverty, Boston: Kluwer

Olson, Mancur (2000). Power and Prosperity (New York: Basic Books). 
Parker, Simon. 2004. The Economics of Self-Employment and Entrepreneurship.

Cambridge UK: Cambridge University Press.

Persson, Torsten and Guido Tabellini (2006). "Democratic Capital: The Nexus of Political and Economic Change". NBER Working Paper 12175.

Rauch, James E. 1991. "Modelling the Informal Sector Informally", Journal of Development Economics, 35, 33 - 47

Robinson, Peter and Edwin Sexton. 1994. "The Effect of Education and Experience on Self-Employment Success". Journal of Business Venturing 9 (2): 141-156.

Samuelson, Paul A. 2009. "Advances of Total Factor Productivity and Entrepreneurial Innovations", in A. Acs and Strom (eds): Entrepreneurship, Growth and Public Policy, Cambridge: Cambridge University Press.

Schneider, Friedrich and Andreas Buehn (2009). "Shadow Economies and Corruption All Over the World: Revised Estimates for 120 Countries", Economics, 2, 1-53.

Schneider, F. and Enste, D. (2000). Shadow Economies: Size, Causes, and Consequences. The Journal of Economic Literature, 38(1): 77-114.

Rodrik, Dani. 2000. "Institutions for High-Quality Growth: What They Are and How to Acquire Them". Studies in Comparative International Development 35 (3): 3 - 31.

Schumpeter, Joseph. 1934. The Theory of Economic Development. Cambridge, MA: Harvard University Press.

Van Stel, André, David Storey and Roy Thurik. 2007. "The Effect of Business Regulations on Nascent and Young Business Entrepreneurship". Small Business Economics 28 (2-3): $171-186$.

Wennekers, Sander, André van Stel, Roy Thurik and Paul Reynolds. 2005. "Nascent Entrepreneurship and the Level of Economic Development". Small Business Economics 24 (3): $293-309$. 
Williamson, O. (2000). "The New Institutional Economics", Journal of Economic Literature, 38 (3), 595-613. 
Figure 1. The shadow economy and the startup rate

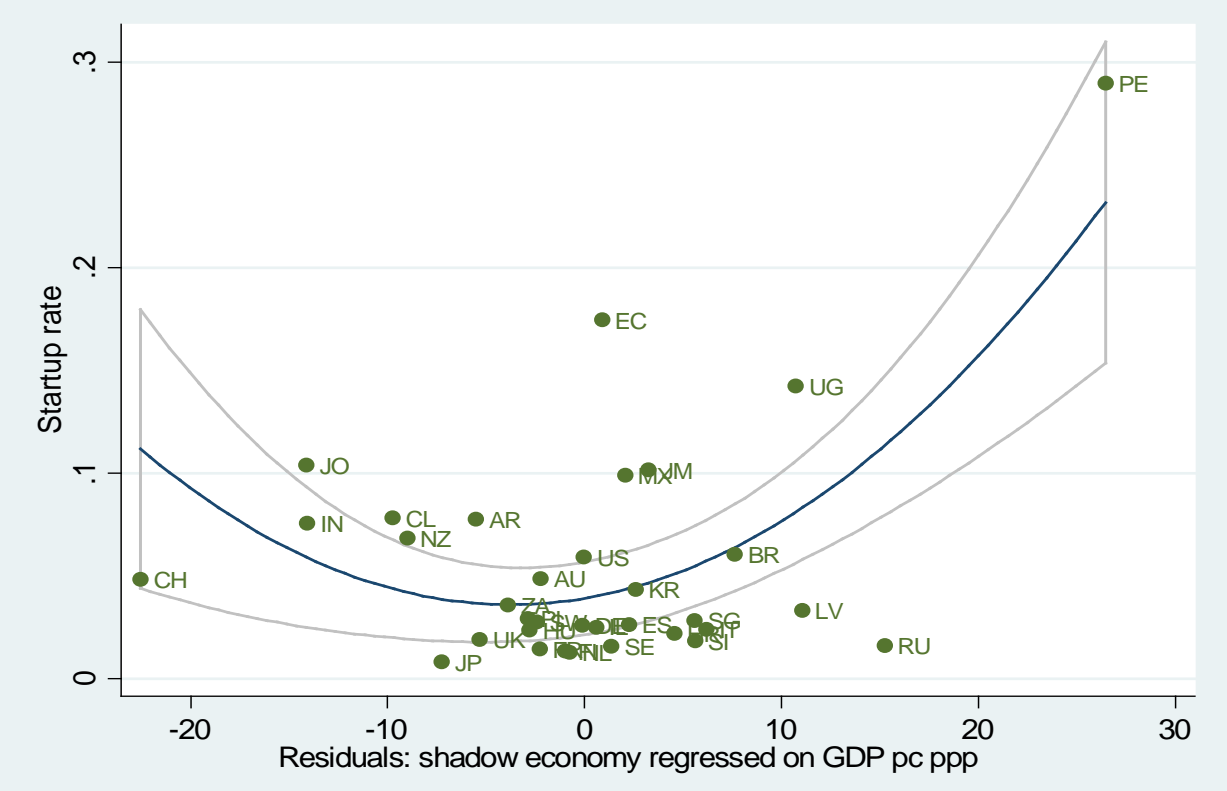


Table 1. Summary statistics

\begin{tabular}{|c|c|c|c|c|}
\hline Variable & Mean & $\begin{array}{r}\text { Std.D } \\
\text { ev. }\end{array}$ & Min & Max \\
\hline Startup (nascent entrepreneur) & .04 & .20 & 0 & 1 \\
\hline Female & .52 & .50 & 0 & 1 \\
\hline Owner/manager of existing business(es) & .07 & .26 & 0 & 1 \\
\hline Business angel in last three years & .04 & .19 & 0 & 1 \\
\hline Knows other entrepreneurs & .34 & .48 & 0 & 1 \\
\hline Education: post-secondary or more & .21 & .41 & 0 & 1 \\
\hline Education: higher & .10 & .30 & 0 & 1 \\
\hline Education: secondary or more & .64 & .48 & 0 & 1 \\
\hline Currently in employment & .54 & .50 & 0 & 1 \\
\hline Age & 43.2 & 15.87 & 14 & 99 \\
\hline Fear of failure would not prevent from starting a business & .63 & .48 & 0 & 1 \\
\hline Believes that does not have skills to start a new business & .52 & .50 & 0 & 1 \\
\hline $\begin{array}{l}\text { Natural logarithm of GDP per capita (purchasing power } \\
\text { parity) }\end{array}$ & 10.01 & .67 & 6.69 & 10.68 \\
\hline Annual GDP growth rate & 2.77 & 2.51 & -10.89 & 10.60 \\
\hline $\begin{array}{l}\text { Effective constraints on executive branch of the government } \\
\text { (Polity IV) }\end{array}$ & 6.64 & 1.06 & 3 & 7 \\
\hline Percentage share of government expense in GDP & 31.11 & 8.97 & 10.45 & 48.03 \\
\hline Percentage share of shadow economy in GDP & 17.45 & 8.86 & 7.2 & 60.30 \\
\hline Business freedom (Heritage Fundation/Wall Street Journal) & 75.76 & 9.78 & 55 & 100 \\
\hline $\begin{array}{l}\text { Durability of democracy (years uninterrupted under } \\
\text { democracy (Polity IV) }\end{array}$ & 62.55 & 56.70 & 1 & 196 \\
\hline
\end{tabular}


Table 2. Simple correlations between the macro level variables and entrepreneurial entry

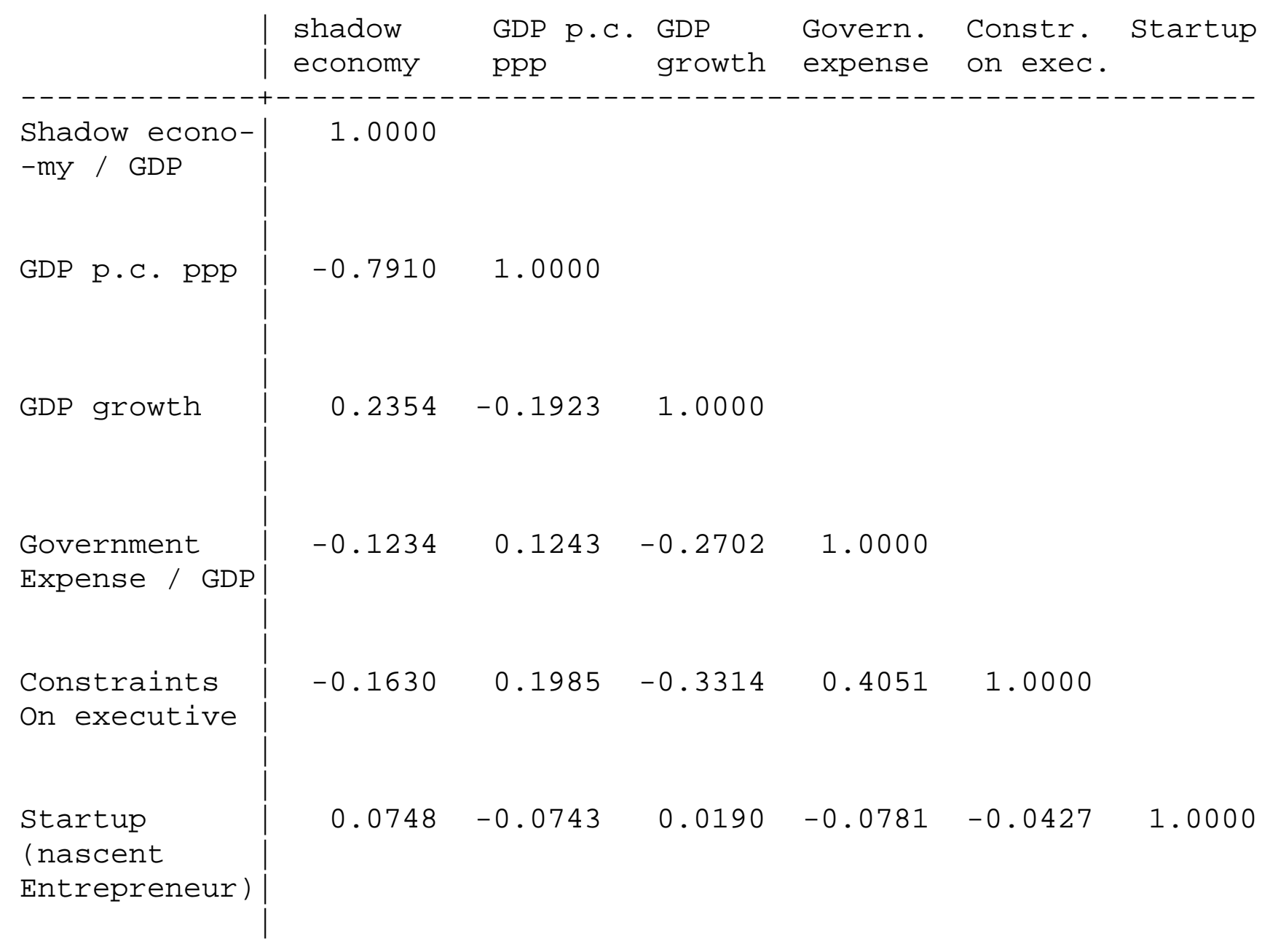

(The table shows R2) 
Table 3 Correlation between shadow economy and expected level of competition (using the small subsample for which the latter variable is available)

3a/ For all start-ups

\begin{tabular}{|c|c|c|}
\hline & $\begin{array}{l}\text { expected } \\
\text { compet. }\end{array}$ & $\begin{array}{l}\text { shadow } \\
\text { economy/GDP }\end{array}$ \\
\hline - - - - - - - - - - - & $--_{-}^{-}---$ & - - - - - \\
\hline expected & 1.0000 & \\
\hline level of & & \\
\hline competition & 52100 & \\
\hline shadow econo- & -0.0719 & 1.0000 \\
\hline my / GDP & $\odot .00 \odot \odot$ & \\
\hline & 41712 & $4.5 e+05$ \\
\hline
\end{tabular}

3b/ For high growth start-ups (more than 10 jobs expected)

\begin{tabular}{l|cc} 
& $\begin{array}{l}\text { expected } \\
\text { compet. }\end{array}$ & $\begin{array}{l}\text { shadow } \\
\text { economy/GDP }\end{array}$ \\
\hline \begin{tabular}{l|r} 
expected \\
level of \\
competition
\end{tabular} & 1.0000 & \\
shadow econo- & $\begin{array}{r}-0.1547 \\
0.0000\end{array}$ & 1.0000 \\
my / GDP & 857 & 3074
\end{tabular}

Remarks:

$1 /$ the table reports simple correlation coefficients, probability and number of observations.

2/ Due to the way the competition is coded in GEM dataset, the results imply that the size of the shadow economy is positively associated with more competition for startups, and particularly for high-expectations startups.

The competition variable is coded in the following way:

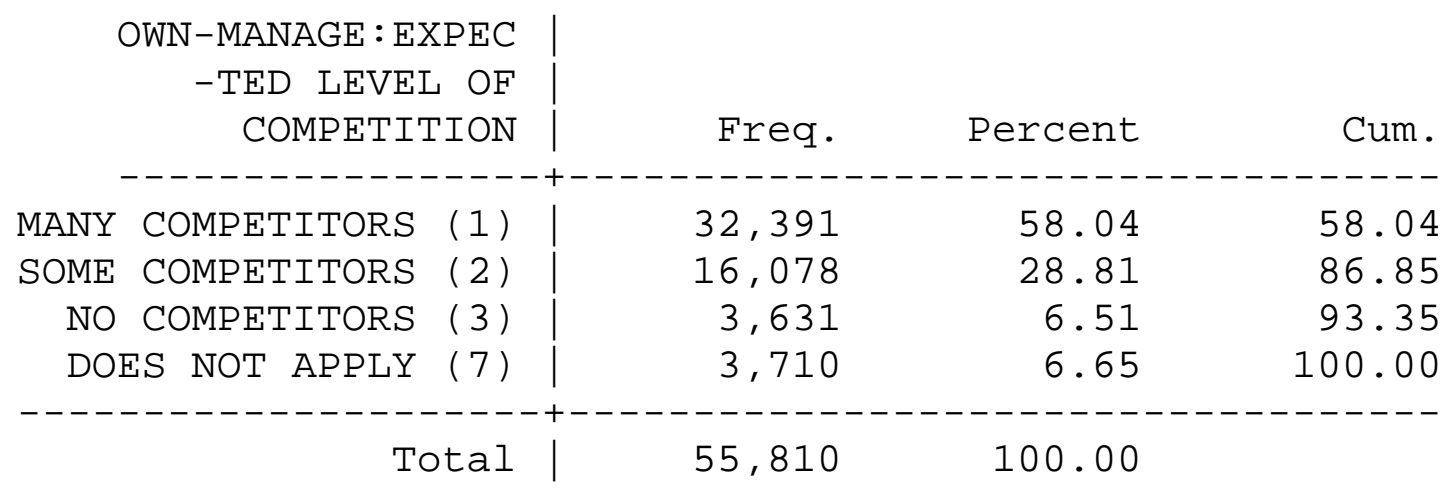

3/ In correlations reported above "Does not apply" is transformed into missing. 
Table 4. Correlations between alternative instruments, the dependent variable and the endogenous variables

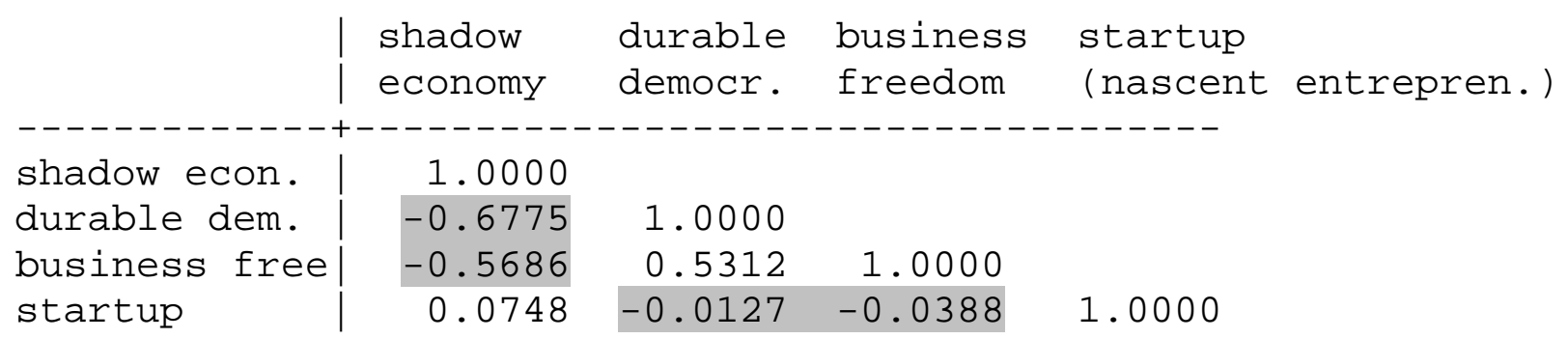


Table 5. Determinants of probability of startup: linear and logarithmic shadow economy. IV Probit model.

(1) (2)

Shadow Econ/GDP

Nat. log. of Shadow econ.

Female

Owner/man. of exist.business

Business angel in last 3 years

Knows entrepreneurs

Education: postsec. or more

Education: higher

Education: secondary or more

In employment

Age

Age squared

No fear of failure

No confidence in own skills

Nat. Log. of GDP pc (ppp)

Annual GDP growth rate

Constraints on executive

Gov. expense / GDP

Constant

Annual dummies

$0.0561+$

$(0.0287)$
$0.108 * * *$

$-0.0101+$
$(0.00601)$
(2) (3)

$-0.0171 *$

(0.00724)
(4)

(5)

(0.00983)

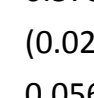


Table 5. Continued
(1)
(2)
(3)
(4)
(5)
(6)

Instruments for shadow economy:

Durability of democracy

Business freedom

Number of observations

Athrho

Insigma
Yes

No

246288

$0.107^{*}$

(0.0419)

$1.585^{* * *}$

(0.150)
No

Yes

239817

$0.184 * *$

(0.0571)

$1.584 * * *$

(0.145)
Yes

Yes

239817

$0.127 * *$

(0.0488)

$1.457^{* * *}$

(0.164)
Yes

No

246288

$0.0696 *$

(0.0320)

$-1.677^{* * *}$

(0.0998)
No

Yes

239817

$0.139 * *$

(0.0523)

$-1.319 * * *$

(0.0865)
Yes

Yes

239817

$0.0612+$

(0.0364)

$-1.771 * * *$

(0.103) 
Table 6. Determinants of probability of startup: cubic shadow economy. IV Probit \& Probit.

Female

(7)

(8)

(9)

(10)

(11)

\begin{tabular}{|c|c|c|c|c|c|}
\hline & $(0.0183)$ & $(0.0183)$ & $(0.0183)$ & $(0.0182)$ & $(0.0177)$ \\
\hline \multirow[t]{2}{*}{ Owner/man. of exist.business } & $-0.229 * * *$ & $-0.239 * * *$ & $-0.232 * * *$ & $-0.229 * * *$ & $-0.230 * * *$ \\
\hline & (0.0359) & $(0.0398)$ & $(0.0364)$ & $(0.0358)$ & $(0.0361)$ \\
\hline \multirow[t]{2}{*}{ Business angel in last 3 years } & $0.306 * * *$ & $0.266 * * *$ & $0.313^{* * *}$ & $0.307 * * *$ & $0.318 * * *$ \\
\hline & $(0.0318)$ & $(0.0483)$ & $(0.0335)$ & $(0.0313)$ & $(0.0305)$ \\
\hline \multirow[t]{2}{*}{ Knows entrepreneurs } & $0.373 * * *$ & $0.376 * * *$ & $0.376^{* * *}$ & $0.373 * * *$ & $0.371 * * *$ \\
\hline & $(0.0206)$ & $(0.0291)$ & $(0.0209)$ & $(0.0206)$ & $(0.0210)$ \\
\hline \multirow[t]{2}{*}{ Education: postsec. or more } & $0.0569 *$ & $0.0489 *$ & $0.0551 *$ & $0.0568 *$ & $0.0592 *$ \\
\hline & $(0.0257)$ & $(0.0241)$ & $(0.0269)$ & $(0.0258)$ & $(0.0259)$ \\
\hline \multirow[t]{2}{*}{ Education: higher } & $0.111 * * *$ & 0.0583 & $0.117^{* * *}$ & $0.112 * * *$ & $0.113^{* * *}$ \\
\hline & $(0.0277)$ & (0.0398) & $(0.0280)$ & $(0.0273)$ & $(0.0281)$ \\
\hline \multirow[t]{2}{*}{ Education: secondary or more } & $0.0620 *$ & -0.00332 & $0.0580^{*}$ & $0.0627^{*}$ & $0.0712 * *$ \\
\hline & $(0.0257)$ & $(0.0368)$ & $(0.0269)$ & $(0.0260)$ & $(0.0252)$ \\
\hline \multirow[t]{2}{*}{ In employment } & 0.0393 & 0.0651 & 0.0417 & 0.0389 & 0.0371 \\
\hline & $(0.0390)$ & $(0.0481)$ & $(0.0405)$ & $(0.0388)$ & (0.0397) \\
\hline \multirow[t]{2}{*}{ Age } & $0.0199 * *$ & $0.0221 * *$ & $0.0202 * *$ & $0.0199 * *$ & $0.0199 * *$ \\
\hline & $(0.00694)$ & $(0.00745)$ & $(0.00725)$ & $(0.00694)$ & $(0.00707)$ \\
\hline \multirow[t]{2}{*}{ Age squared } & $-0.00034 * * *$ & $-0.00037 * * *$ & $-0.00034 * * *$ & $-0.00038 * * *$ & $-0.00037^{* *}$ \\
\hline & (8.39e-05) & $(9.03 e-05)$ & (8.76e-05) & $(8.40 e-05)$ & $(8.52 \mathrm{e}-05)$ \\
\hline \multirow[t]{2}{*}{ No fear of failure } & $0.230 * * *$ & $0.208 * * *$ & $0.239 * * *$ & $0.230 * * *$ & $0.232 * * *$ \\
\hline & $(0.0211)$ & $(0.0259)$ & $(0.0213)$ & (0.0209) & $(0.0214)$ \\
\hline \multirow[t]{2}{*}{ No confidence in own skills } & $-0.703 * * *$ & $-0.665 * * *$ & $-0.713 * * *$ & $-0.704 * * *$ & $-0.706 * * *$ \\
\hline & $(0.0268)$ & $(0.0354)$ & $(0.0285)$ & $(0.0267)$ & $(0.0271)$ \\
\hline \multirow[t]{2}{*}{ Nat. Log. of GDP pc (ppp) } & $-0.112 * *$ & $-0.316^{*}$ & $-0.131 * *$ & $-0.110 * *$ & $-0.138 * * *$ \\
\hline & $(0.0373)$ & $(0.127)$ & $(0.0454)$ & $(0.0360)$ & $(0.0383)$ \\
\hline \multirow[t]{2}{*}{ Annual GDP growth rate } & -0.00466 & 0.00759 & -0.00170 & -0.00503 & -0.00809 \\
\hline & $(0.00796)$ & $(0.0192)$ & $(0.00892)$ & $(0.00776)$ & $(0.00592)$ \\
\hline \multirow[t]{2}{*}{ Constraints on executive } & $0.0515^{* *}$ & $0.0649+$ & $0.0420 *$ & $0.0505^{* *}$ & $0.0402 *$ \\
\hline & $(0.0186)$ & $(0.0349)$ & $(0.0181)$ & $(0.0183)$ & $(0.0181)$ \\
\hline \multirow[t]{2}{*}{ Gov. expense / GDP } & $-0.0147^{* * *}$ & $-0.0123^{*}$ & $-0.0152 * * *$ & $-0.0147^{* * *}$ & $-0.0139 * * *$ \\
\hline & $(0.00263)$ & $(0.00512)$ & (0.00259) & $(0.00264)$ & $(0.00270)$ \\
\hline \multirow[t]{2}{*}{ Shadow Econ/GDP } & $-0.0267 * *$ & $-0.106 * *$ & $-0.0245^{*}$ & $-0.0254 * *$ & $-0.0170+$ \\
\hline & (0.00990) & $(0.0404)$ & $(0.0112)$ & $(0.00787)$ & $(0.00875)$ \\
\hline \multirow[t]{2}{*}{ Shadow econ. Squared } & $0.000540 * *$ & $0.00172 * *$ & $0.000460 *$ & $0.000515^{* * *}$ & $0.000283+$ \\
\hline & $(0.000164)$ & $(0.000661)$ & $(0.000186)$ & $(0.000125)$ & $(0.000170)$ \\
\hline \multirow[t]{2}{*}{ Constant } & -0.495 & 2.402 & -0.262 & -0.519 & -0.291 \\
\hline & $(0.415)$ & $(1.624)$ & $(0.539)$ & $(0.384)$ & $(0.381)$ \\
\hline Annual dummies & Yes & Yes & Yes & Yes & Yes \\
\hline
\end{tabular}


Table 6. Continued
(7)
(8)
(9)
(10)
(11)

Instruments for shadow economy:

Durability of democracy

Yes

No

Yes

No

No

Business freedom

No

Yes

Yes

No

Observations

246288

239817

239817

No

244556

Athro

$0.00579 \quad 0.205+\quad-0.0161$

$\begin{array}{lll}(0.0200) & (0.109) & \text { (0.0215) }\end{array}$

Insigma

$0.412 * *$

$0.850 * * *$

$0.387^{* * *}$

(0.129)

(0.0819)

(0.118)

Peru included

Yes

Yes

Yes

Yes

No 
Table 7. Determinants of probability of startup: interactive terms. Probit model.

Female

Owner/man. of exist.business

Business angel in last 3 years

Knows entrepreneurs

Education: postsec. or more

Education: higher

Education: secondary or more

In employment

Age

Age squared

No fear of failure

No confidence in own skills

Nat. Log. of GDP pc (ppp)

Annual GDP growth rate

Constraints on executive

Gov. expense / GDP

Shadow Econ/GDP

Shadow Econ. Squared

Shadow econ. X No fear

Shadow econ. X Gov. Expense

Shadow econ. X Exec. Constraints
(13)

(14)

(12)

$-0.158 * * *$

$-0.157 * * *$

$-0.157^{* * *}$

(0.0182)

(0.0182)

(0.0182)

$-0.229 * * *$

$-0.229 * * *$

$-0.231 * * *$

(0.0359)

(0.0358)

(0.0355)

$0.307^{* * *} \quad 0.306 * * * \quad 0.309 * * *$

(0.0313)

(0.0313)

(0.0313)

$0.373 * * *$

$0.372 * * *$

$0.372 * * *$

(0.0206)

(0.0208)

(0.0209)

$0.0569 *$

$0.0562 *$

$0.0601^{*}$

(0.0258)

(0.0259)

(0.0254)

$0.112^{* * *}$

$0.113^{* * *}$

$0.112 * * *$

(0.0273)

(0.0268)

(0.0268)

$0.0628^{*}$

$0.0630 *$

$0.0651^{*}$

(0.0260)

(0.0261)

(0.0253)

0.0386

0.0396

0.0387

(0.0388)

(0.0394)

(0.0391)

$0.0199 * *$

$0.0199 * *$

$0.0199 * *$

(0.00694)

(0.00693)

(0.00693)

$\begin{array}{lll}- & - & - \\ 0.000337 * * & 0.000337 * * * & 0.000335^{* * *}\end{array}$

(8.40e-05)

(8.39e-05)

(8.38e-05)

$0.211^{* * *}$

$0.230 * * *$

$0.232 * * *$

(0.0405)

(0.0211)

(0.0208)

$-0.704 * * * \quad-0.704 * * * \quad-0.708 * * *$

$(0.0268)$

(0.0267)

(0.0267)

$-0.110 * *$

$-0.114 * *$

$-0.148 * * *$

(0.0359)

(0.0393)

(0.0423)

$\begin{array}{lll}-0.00501 & -0.00558 & -0.0111^{*}\end{array}$

(0.00778)

(0.00813)

(0.00564)

$0.0506 * *$

$0.0507^{* *}$

$-0.00312$

(0.0183)

(0.0183)

(0.0297)

$-0.0147^{* * *}$

$-0.0164 * *$

$-0.0139 * * *$

(0.00265)

$(0.00490)$

(0.00264)

$\begin{array}{lll}-0.0261^{* *} & -0.0298+ & -0.0442^{* * *}\end{array}$

(0.00816)

(0.0163)

(0.0106)

$0.000516^{* * *}$

$0.000549 * *$

$0.000554 * * *$

(0.000126)

(0.000175)

(0.000110)

0.00104

(0.00160)

0.000104

(0.000258)

$0.00249 * *$

(0.000958) 
Table 7. Continued

Constant

Observations
(12)

$-0.506$

(0.393)

246288
(13)

$-0.426$

(0.530)

246288
(14)

0.191

(0.537)

246288 
Table 8. Determinants of probability of high growth aspiration E startup (>10 jobs): linear and logarithmic shadow economy. IV Probit

(15) (16) (17) (18) (19) (20)

Shadow Econ/GDP

Nat. log. of Shadow econ.

$-0.00771-0.0326 * * \quad-0.0142+$

$\begin{array}{lll}(0.00665) & (0.0120) \quad(0.00846)\end{array}$

Female

$-0.279 * * * \quad-0.277 * * *$

$-0.282 * * *$

$-0.109$

$-0.569 * *$

$-0.132$

(0.0920)

(0.206)

(0.108)

$-0.279 * * *$

$-0.279 * * *$

$-0.282 * * *$

Owner/man. of exist.business

(0.0192) (0.0192)

(0.0191)

(0.0192)

(0.0191)

(0.0190)

$-0.167 * * * \quad-0.168 * * *$

$-0.162 * * *$

$-0.165 * * *$

$-0.167 * * *$

$-0.160 * * *$

(0.0387)

(0.0396)

Business angel in last 3 years

$0.335^{* * *} \quad 0.312^{* * *}$

(0.0396)

(0.0385)

(0.0394)

(0.0395)

$0.325^{* * *}$

$0.335 * * *$

$0.309 * * *$

$0.330 * * *$

(0.0508) (0.0603)

(0.0552)

(0.0511)

(0.0606)

(0.0544)

Knows entrepreneurs

$0.392 * * * \quad 0.403 * * *$

$0.396 * * *$

$0.393 * * *$

$0.403 * * *$

$0.394 * * *$

(0.0287) (0.0310)

(0.0295)

(0.0288)

(0.0323)

(0.0292)

Education: postsec. or more

0.0800 *

$0.0723+$

$0.0820 *$

$0.0793 *$

$0.0699+$

0.0832*

(0.0366) (0.0378)

(0.0372)

(0.0367)

(0.0370)

(0.0375)

Education: higher

$0.166 * * *$

$0.132 * *$

$0.162^{* * *}$

$0.169 * * *$

$0.129 * *$

$0.175^{* * *}$

Education: secondary or more

(0.0478) (0.0474)

(0.0469)

(0.0476)

(0.0459)

(0.0472)

$0.101^{* *} \quad 0.0601+$

0.0890**

$0.0966 * *$

0.0411

$0.0874 *$

(0.0324) (0.0330)

(0.0345)

(0.0335)

(0.0329)

(0.0359)

In employment

0.0418

0.0437

0.0373

(0.0345) (0.0373)

(0.0357)

0.0414

0.0490

0.0340

$0.00535 \quad 0.00825$

0.00725

(0.0348)

(0.0398)

(0.0356)

Age

Age squared

(0.00860)

(0.00932)

(0.00927)

0.00551

0.00890

0.00723

$-0.000161 \quad-0.000199+\quad-0.000188+$

(0.00865)

(0.00945)

(0.00934)

(0.000105) (0.000114)

(0.000113)

No fear of failure

No confidence in own skills

$0.290 * * * \quad 0.280 * * *$

(0.0259) (0.0261)

$0.292 * * *$

$-0.000164$

$-0.000209+$

$-0.000188$

(0.000106)

(0.000116)

(0.000115)

$-0.598 * * * \quad-0.582 * * *$

(0.0347) (0.0400)

(0.0264)

$0.289 * * *$

$0.271 * * *$

$0.293 * * *$

$-0.598 * * *$

(0.0259)

(0.0270)

(0.0265)

$-0.0604-0.339 *$

(0.0372)

$-0.599 * * *$

$-0.578 * * *$

$-0.603 * * *$

Nat. Log. of GDP pc (ppp)

Annual GDP growth rate

(0.0718)

(0.133)

$-0.138$

(0.0348)

$(0.0405)$

(0.0369)

$0.00619 \quad 0.0150$

(0.108)

$-0.0413$

$-0.281 *$

$-0.0593$

(0.00929) (0.0125)

0.0124

(0.0553)

(0.116)

(0.0696)

(0.0119)

0.0241

0.0198

(0.0279) (0.0433)

.00548

0.0128

0.00970

Constraints on executive

Gov. expense / GDP

$-0.0111 * * \quad-0.0122 * *$

(0.00359) (0.00460)

$-1.654^{*}$

1.545

(0.765)

(1.516)

Annual dummies
Yes
0.0126

(0.0314)

$-0.0112 * *$

(0.00361)

$-0.739$

(0.00919)

(0.0137)

0.0254

(0.0111)

0.0249

(0.0409)

0.0174

(0.0291)

$-0.0115^{* *}$

$-0.0113^{*}$

(0.0296)

(0.00378) (0.00476)

-1.669* 1.957

(1.217)

(0.716)

(1.665)

Yes
$-0.0117^{* *}$

(0.00372)

$-1.403$

(0.943)

Yes 
Table 8. Follow up
(15)
(16)
(17)
(18)
(19)
(20)

Instruments for shadow economy:

Durability of democracy

Yes No Yes Yes No Yes

Business freedom

athrho

No Yes Yes No Yes Yes

$0.0782+\quad 0.206 * * \quad 0.110 * \quad 0.0420 \quad 0.166 * * \quad 0.0441$

Insigma

$\begin{array}{lllllll}(0.0451) & (0.0664) & (0.0502) & (0.0339) & (0.0611) & (0.0374\end{array}$

$\begin{array}{llllll}1.578 * * * & 1.577^{* * *} & 1.449 * * * & 1.679 * * * & 1.321 * * * & 1.774 * * *\end{array}$

Observations

$\begin{array}{llllll}(0.149) & (0.144) & (0.162) & (0.100) & (0.0865) & (0.103)\end{array}$


Table 9. Determinants of probability of high growth aspiration startup (>10 jobs): cubic shadow economy. IV Probit \& Probit
(21)
(22)
(23)
(24)
(25)

Female

$\begin{array}{ll}-0.280 * * * & -0.280 * * * \\ (0.0194) & (0.0199)\end{array}$

$\begin{array}{ll}-0.283 * * * & -0.281 * * * \\ (0.0192) & (0.0194)\end{array}$

$-0.285^{* * *}$

Owner/man. of exist.business

$-0.164 * * *$

$-0.171 * * *$

$-0.159 * * *$

$-0.164 * * *$

(0.0197)

Business angel in last 3 years

(0.0389)

(0.0391)

(0.0399) (0.0388)

$-0.169 * * *$

$0.329 * * *$

$0.271 * * *$

$0.329 * * *$

$0.327^{* * *}$

(0.0398)

(0.0525) (0.0690)

(0.0553)

(0.0519)

$0.337 * * *$

Knows entrepreneurs

$0.388^{* * *}$

$0.386 * * *$

$0.388 * * *$

(0.0531)

(0.0297)

(0.0402)

(0.0299)

$0.388 * * *$

$0.382 * * *$

Education: postsec. or more

$0.0793^{*}$

0.0763*

0.0838*

(0.0300)

(0.0303)

(0.0351)

(0.0362)

(0.0363)

0.0796*

$0.0832 *$

Education: higher

$0.165^{* * *}$

$0.101+$

$0.174 * * *$

(0.0349)

(0.0351)

(0.0470)

(0.0552)

(0.0479)

$0.163^{* * *}$

$0.169 * * *$

Education: secondary or more

$0.104^{* *}$

0.0239

$0.100 * *$

(0.0463)

(0.0473)

(0.0346)

(0.0409)

(0.0370)

$0.102 * *$

$0.112 * *$

In employment

0.0447

0.0610

0.0335

(0.0341)

(0.0348)

(0.0351)

(0.0434)

(0.0360)

0.0459

0.0542

Age

0.00549

0.00972

0.00700

(0.0352)

(0.0349)

(0.00862)

(0.00941)

(0.00931)

0.00558

0.00530

Age squared

$-0.000163$

$-0.000220+$

(0.00873)

(0.000105) (0.000116)

(0.000114)

(0.00862)

$-0.000158$

No fear of failure

$0.285^{* * *}$

$0.251 * * *$

$0.290 * * *$

(0.000106)

$(0.0267)$

(0.0330)

(0.0274)

$(0.000105)$

$0.292 * * *$

No confidence in own skills

$-0.595 * * * \quad-0.546 * * *$

$-0.603 * * *$

$0.285^{* * *}$

(0.0271)

(0.0346)

(0.0511)

(0.0366)

(0.0266)

$-0.596 * * *$

Nat. Log. of GDP pc (ppp)

$$
0.0293
$$

$-0.198$

(0.150)

0.0285

(0.0352)

(0.0429)

(0.0534)

$(0.0344)$

$-0.00759$

Annual GDP growth rate

0.00793

0.0177

0.00967

(0.0436)

(0.0446)

(0.0123)

(0.0243)

(0.0138)

0.00863

0.00458

0.0102

0.0395

0.00818

(0.0128)

(0.0110)

Constraints on executive

(0.0205) (0.0431)

$(0.0205)$

0.0124

0.00187

$$
-
$$

Gov. expense / GDP

$0.00967 * * \quad-0.00644$

$-0.0101 * * \quad-0.00949 * *$

(0.0213)

Shadow Econ/GDP

Shadow economy squared

(0.00333)

$0.00877^{* *}$

$-0.0206+\quad-0.117^{*}$

$-0.0177$

(0.00314)

(0.00303)

$$
\text { (0.0121) }
$$

(0.0456)

(0.0134)

$-0.0242 *$

$-0.0141$

$0.000398+\quad 0.00189 *$

0.000334

(0.00957)

(0.0107)

(0.000205) (0.000770)

(0.000229)

0.000466**

0.000181

Constant

$-2.386^{* * *} \quad 0.848$

$-2.405^{* * *}$

(0.000153)

(0.000200)

Annual Dummies

(0.480)

(1.897)

Yes

Yes

(0.614)

$-2.317^{* * *}$

$-2.059 * * *$

Peru included

Yes

Yes

Yes

(0.468)

(0.460)

Yes

No 
Table 9. Follow up
(21)
(22)
(23)
(24)
(25)

Instruments for shadow econ.:

Durability of democracy

$\begin{array}{lllll}\text { Yes } & \text { No } & \text { Yes } & \text { No } & \text { No }\end{array}$

Business freedom

Athrho

No Yes Yes No No

Insigma

$\begin{array}{lll}-0.0158 & 0.246 * & -0.0324\end{array}$

$\begin{array}{lll}(0.0225) & (0.124) \quad(0.0261)\end{array}$

$0.406 * * \quad 0.847 * * * \quad 0.382 * *$

$\begin{array}{lll}(0.130) & (0.0826) \quad(0.119)\end{array}$

$244300 \quad 237936 \quad 237936$

244300

242666 
Table 10. Determinants of probability of high growth aspiration startup ( $>10$ jobs): interactive terms. Probit model.

Female

(26)

(27)

(28)

Female
Owner/man. of exist.business
Business angel in last 3 years
Knows entrepreneurs

$-0.281$

$-0.281 * * * \quad-0.280 * * *$

$(0.0194)$

(0.0193) (0.0194)

$-0.164 * * * \quad-0.164 * * * \quad-0.166 * * *$

$\begin{array}{lll}(0.0389) & (0.0389) \quad(0.0384)\end{array}$

$0.327 * * * \quad 0.327 * * * \quad 0.331 * * *$

$\begin{array}{lll}(0.0519) & (0.0521) & \text { (0.0518) }\end{array}$

$0.388 * * * \quad 0.388^{* * *} \quad 0.387^{* * *}$

$\begin{array}{lll}(0.0299) & (0.0309) & (0.0302)\end{array}$

Education: postsec. or more

0.0796* $0.0795 * 0.0844$ *

Education: higher

$\begin{array}{lll}(0.0349) & (0.0349) \quad(0.0346)\end{array}$

$0.163^{* * *} \quad 0.164^{* * *} \quad 0.164^{* * *}$

Education: secondary or more

$\begin{array}{lll}(0.0463) & (0.0461) & (0.0459)\end{array}$

$0.102^{* *} \quad 0.102^{* *} \quad 0.107^{* *}$

$(0.0341) \quad(0.0340) \quad(0.0330)$
0.0458

In employment

$\begin{array}{lll}0.0458 & 0.0460 & 0.0453\end{array}$

$\begin{array}{lll}(0.0350) & (0.0353) \quad(0.0352)\end{array}$

Age

$\begin{array}{lll}0.00558 & 0.00558 & 0.00550\end{array}$

$\begin{array}{lll}(0.00861) & (0.00861) & (0.00861)\end{array}$

Age squared

$\begin{array}{lll}-0.000164 & -0.000164 & -0.000162\end{array}$

$\begin{array}{lll}(0.000105) & (0.000105) & (0.000105)\end{array}$

No fear of failure

$0.274 * * * \quad 0.285^{* * *} \quad 0.287^{* * *}$

$\begin{array}{lll}(0.0579) & (0.0268) \quad(0.0268)\end{array}$

No confidence in own skills $\quad-0.594 * * * \quad-0.594 * * * \quad-0.598 * *$

$\begin{array}{lll}(0.0344) & (0.0344) \quad(0.0346)\end{array}$

Nat. Log. of GDP pc (ppp) $\quad 0.0248 \quad 0.0240 \quad-0.0332$

$\begin{array}{lll}(0.0435) & (0.0445) \quad(0.0452)\end{array}$

$0.00866 \quad 0.00852 \quad-0.00108$

Annual GDP growth rate

$\begin{array}{lll}(0.0129) & (0.0129) \quad(0.00945)\end{array}$

Constraints on executive

$0.0125 \quad 0.0124 \quad-0.0640 *$

$\begin{array}{lll}(0.0221) & (0.0223) \quad(0.0298)\end{array}$

Gov. expense / GDP

$\begin{array}{lll}-0.00949 * * & -0.00983 * & -0.00850 * *\end{array}$

$(0.00314) \quad(0.00459) \quad(0.00301)$

Shadow Econ/GDP $\quad-0.0247 * * \quad-0.0252 \quad-0.0521 * * *$

Shadow Econ. Squared $\quad 0.000466 * * \quad 0.000473 * 0.000503 * * *$

$\begin{array}{llll}(0.000153) & (0.000219) & (0.000134)\end{array}$

Shadow econ. X No fear $\quad 0.000584$

(0.00290)

Shadow econ. X Gov. Expense

$2.26 \mathrm{e}-05$

(0.000335)

Shadow econ. X Exec. Constraints

$0.00378 * * *$

(0.000909) 
Table 10. Continued

(22)

$-2.310^{* * *}$

(0.474)

244300
(23)

$-2.298^{* * *}-1.275^{*}$

(0.577) (0.553)

$244300 \quad 244300$

Observations 